\title{
Accounting E-Module Integrated with Character Value for the Tenth Grade Vocational Students In Surakarta
}

\author{
Destri Sambara Sitorus ${ }^{1}$, Siswandari ${ }^{2}$, Kristiani $^{3}$
}

\begin{tabular}{l} 
ARTICLE INFO \\
\hline Article History: \\
Received 03.07.2018 \\
Received in revised form \\
21.08 .2018 \\
Accepted \\
Available online 01.10 .2018
\end{tabular}

ABSTRACT

This research is aimed to develop an accounting e-module integrated with character value for the tenth grade vocational students of Business and Management. This research is categorized as research and development (R\&D). The procedure of the research utilized 4D - instructional design model i.e. Define, Design, Develop and Disseminate. The subject of the study is the tenth grade students of Vocational High School 6 Surakarta. The sampling technique uses purposive sampling. Data were collected by questioner. Collected data were categorized as quantitative data and qualitative data. Quantitative data is collected from e-module evaluation. While qualitative data were collected from in the form of advices and commentaries for product upgrade. Both data were analyzed descriptively. The Result of the research shows that accounting e-module integrated with character value is feasible to be implemented as accounting learning media.

Keywords: ${ }^{1}$

(C) 2018 IJERE. All rights resened

Learning Media, E-module, Character Value.

\section{INTRODUCTION}

The availability of learning media and learning source for vocational high school student, specifically in business and management fields, is considered too few. It can be proved by seeing the facts of the field documentation that the teachers in the process of learning activities uses a package book that has been published, besides the delivery techniques are done in a monotonous manner so that, the students become unenthusiastic (Darsono, 2017). This circumstance also happens to the subject of accountancy. The materials of the subjects mostly served in the form of printed book with unattractive covers and monotoni. Meanwhile, the students feel that accountancy is one of the difficult subjects because it consist of systematic calculation, conceptual and logical thinking (Ismawanto, 2007).

The current curriculum which is implemented in the high school is no only emphasizing the aspect of cognitive in the learning process, but also focusing on the affective aspect. This is one of the things that can be seen from the behavior development and student character. In fact that the source of learning and learning media still focusing on cognitive aspect and creativity but still lack of attention to the affective aspect (Pratomo, sarwanto, \& Roemintoyo, 2018). Clayton T. Wukich's research findings (2016) state that the established community network originates from the relationship between individual characters to work together and be supported from all suitable infrastructure. This has a relationship with this research which aims to create a superior generation that is full of good character.

Based on the facts above, there is a need to develop innovative learning tool for accounting learning. In order to make the need fulfilled, we develop learning media in a form of e-module which is integrated to the value of character. And the media is expected to build the positive behavior of the students toward accountancy (Nugraheni \& Purwanti, 2016) and these characters such as honesty and responsibility can be developed in the curriculum.

E-module development is based on the advantage of the e-module, such as interactive, flexible and giving feedback immediately and helping to develop the creativity of students (Nasution, 2006). Based on the several researches, e-module gives positive impact, such as students learning experiences enrichment, more effective than printed module, motivating and giving better learning achievement and become the tool to

\footnotetext{
${ }^{1}$ Corresponding e-mail: destri.sambara@gmail.com, orcid.org/0000-0002-6883-7830

siswandari@staff.uns.ac.id ${ }^{2}$, kristieko95@yahoo.co.id ${ }^{3}$
} 
develop cognitive ability and students' ICT creativity (Sengupta., Huang., Davidson., Edgar., Eden., ElHalwagi., 2017; Woo., 2011; Jeno., Grytnes., Vigdis., Vandvick., 2017; Kim., Pederson., Baldwin., 2011; Pummawan., 2007). By using the e-module is expected to increase the process of the effectiveness and make the learning more efficient and attractive. The e-module development integrated to to the value of character is expected to provide new perspective in developing accountancy learning media and trigger more innovative and motivating media development.

\section{METHOD}

This is research and development. The procedure of the research adopts the steps of 4-D learning program design who suggested by Thiagarajan and consist of the following 4 steps; (1) Define, (2) Design, (3) Develop, dan (4) Disseminate.

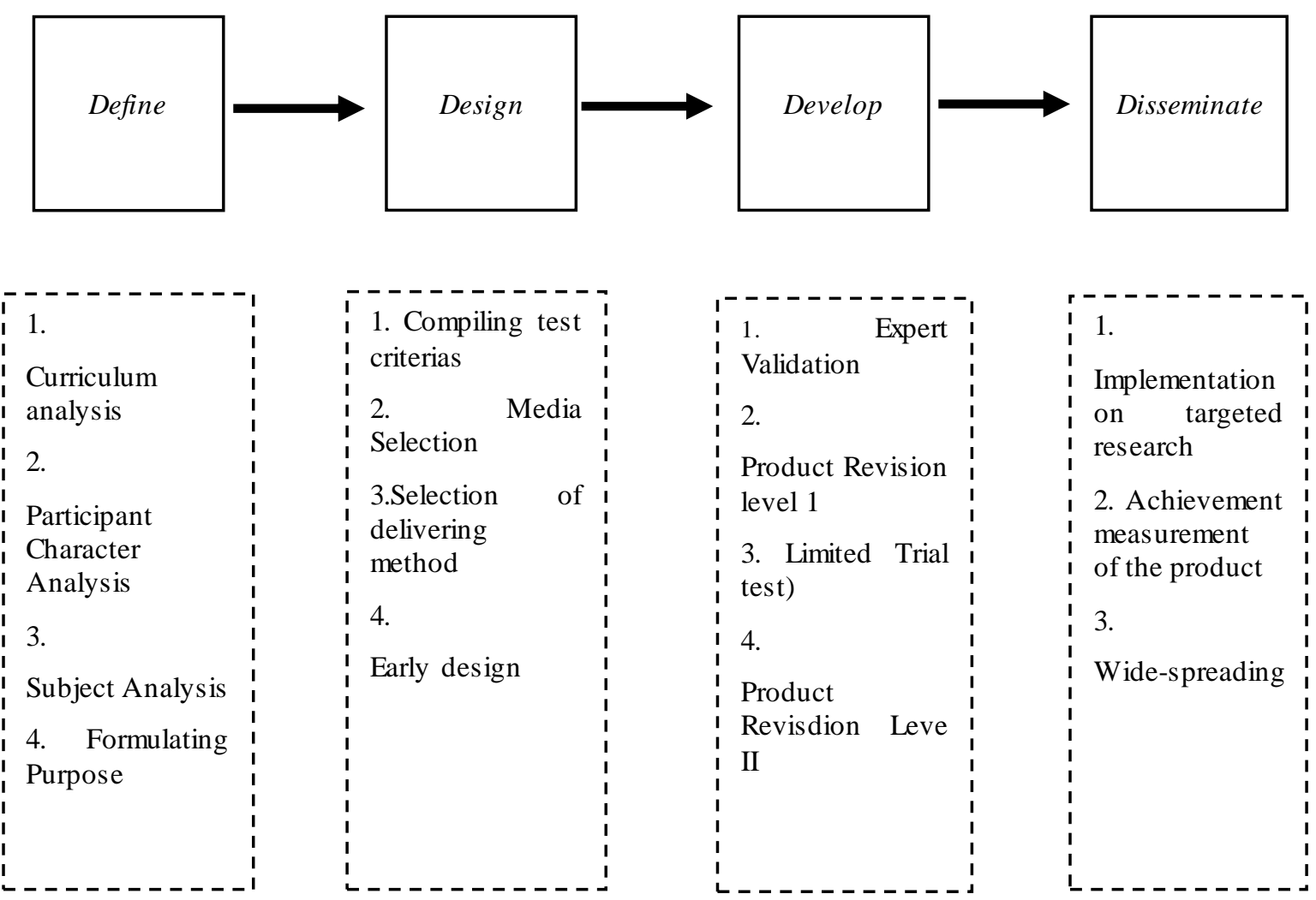

Figure 1. 4D Development Procedure Model

Development steps are committed by doing expert validation and product tryouts. Expert validation is committed by the experts of the subjects study and media, while accounting teachers as practitioners. Experts validation aims to get advice as a basis for revising the product before being tested and getting an assessment of the product being developed. The validated product will be implemented in 2 tryouts, which are limited tryout test and field tryout test. This tryout aims to get advice from students to improve product and get an assessment of the product that haven been developed. The subjects of the research were students of tenth grade of accounting class at SMK Negeri 6 Surakarta. Total of 20 students as subjects in the limited tryout and 32 students as subjects in the field tryout.

Data collected by using questionnaires. Data itself is quantitative and qualitative. Quantitative data is produced by e-mobile scoring. Qualitative data is in form of suggestions and commentary which will be used to fix the developing product. Both data is analyzed descriptively and the result of the evaluation data is conversed from quantitative to qualitative, as it is displayed on Table 1

Table 1. Data conversion from Quantitative to Qualitative 


\begin{tabular}{|c|c|}
\hline Interval Score & Criteria \\
\hline $\mathrm{X}>4,21$ & Very Good \\
\hline $3,40<\mathrm{X} \leq 4,21$ & Good \\
\hline $2,60<\mathrm{X} \leq 3,40$ & Adequate \\
\hline $1,79<\mathrm{X} \leq 2,60$ & Lack \\
\hline $\mathrm{X} \leq 1,79$ & Super lack \\
\hline
\end{tabular}

(Source: Budiyono, 2016)

\section{FINDINGS}

E-module integrated with character value consist of 3 parts, namely preface, content and closing. The preface shows user manual, menu information, silabus, mapping of concept and glosarium. The content is consist of subject study, excercizes, summary and reflection sheet. While closing part is consist of reference list and authors profile.
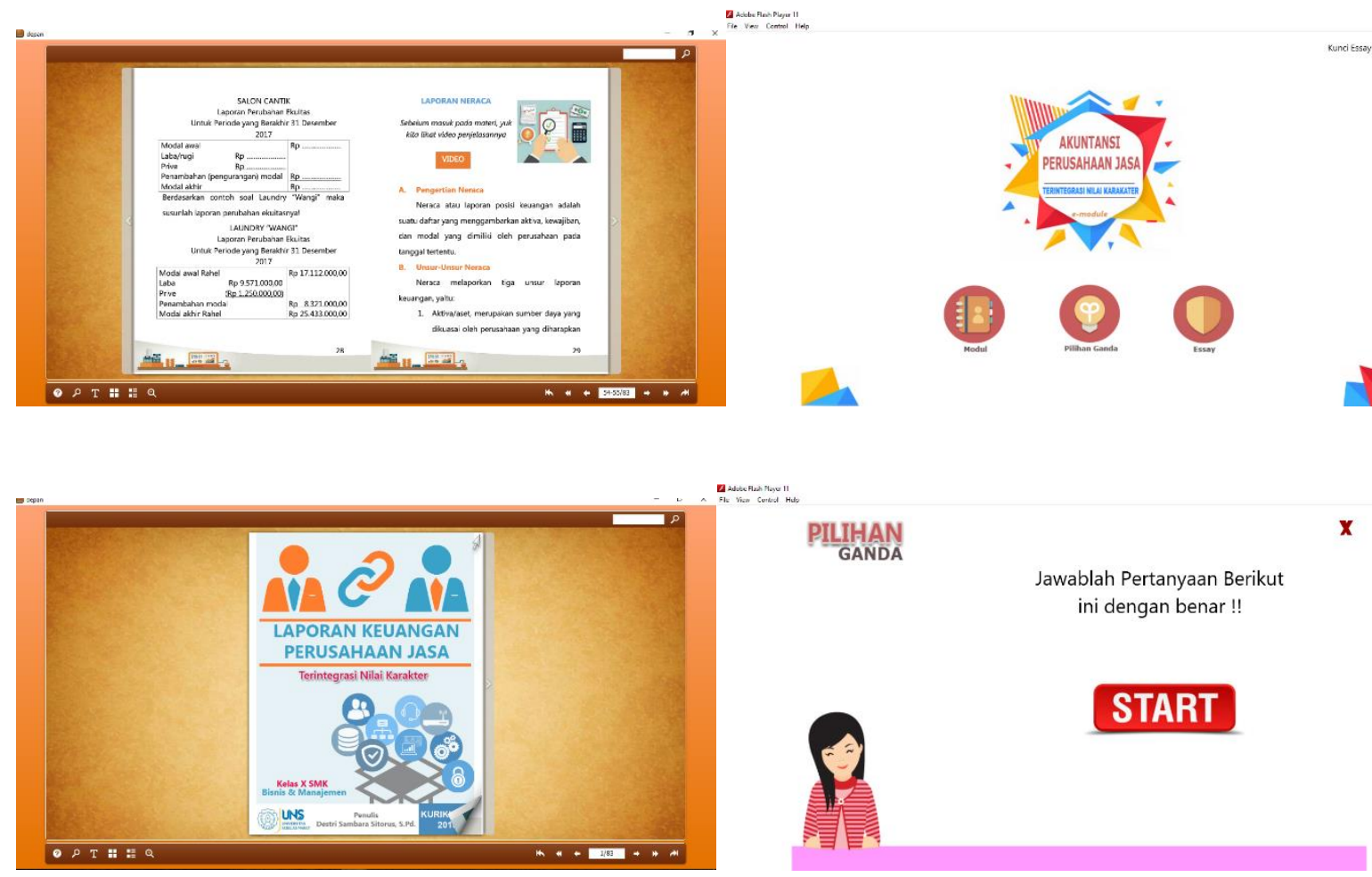

Figure 2. The Interface Of Character Value-Integrated Accounting E-Module

Experts validation is carried out by 2 experts and 1 practitioner. Expert validation consist of 2 people, namely subject study experts and media experts, while practitioner is teacher who teach accounting subjects. Subject study validation was carried out by Khresna Bayu Sangka, S.E., M.M., Ph.D. He is a lecturer in the Accounting Education Study Program, Faculty of Teaching and Training, Sebelas Maret University. He was chosen as a subject study expert because he has more than ten years teaching experience in accounting and understands a broad understanding of accounting. There are two aspects assessed, namely aspects of content and objectives, and instructional aspects. The content and purpose aspects contain the accuracy, completeness and presentation of the material, the suitability of the writing and the language used, and the ease of the material to be understood. The instructional aspects is about presenting material so that it can attract readers, examples and illustrations used, and material flexibility.

Media validation was carried out by Prof. Dr. Nunuk Suryani, M.Pd. she is a lecturer in the Learning Technology Study Program, Faculty of Teaching and Training, Sebelas Maret University. She is a professor in the field of learning media, so that there is no doubt about her knowledge, 
abilities and axpertise in terms of learning media. There is one aspect that is assessed, namely the technical quality aspect which includes readability, ease of use, display quality, and quality of program management.

Validation by practitioner was carried out by Joko Pramono, S.Pd., M.Si., CAP. He is an accounting teacher at SMK Negeri 6 Surakarta. Her undergraduate and postgraduate background are accounting, he has more than 10 years of teaching accounting experience. He was chosen as a practitioner because he knew the students characteristics and learning media suitable for use in accounting learning. Practitioner give a thorough assessment, namely aspects of subject study, aspects of media, and aspects of character education containing. This following are the results of validation carried out by experts and practitioner:

Table 2. Experts validation result

\begin{tabular}{|c|c|c|c|}
\hline \multirow[t]{2}{*}{ Experts } & \multicolumn{3}{|c|}{ Evaluated As pects and Result } \\
\hline & Evaluated Aspects & Average Score & Categories \\
\hline \multirow[t]{3}{*}{$\begin{array}{ll}\text { Subject } & \text { study } \\
\text { experts } & \end{array}$} & $\begin{array}{l}\text { Substanstive and Purpose Aspect } \\
\text { (13 tems) }\end{array}$ & 4,61 & Very Good \\
\hline & Instructional aspect (7 items) & 4,71 & Very Good \\
\hline & Average total score & 4,66 & Very Good \\
\hline \multirow[t]{5}{*}{ Media experts } & Readability aspect (3 items) & 5,00 & Very Good \\
\hline & Convenience of use aspect (1 item) & 5,00 & Very Good \\
\hline & Lay out quality aspect (7 items) & 5,00 & Very Good \\
\hline & $\begin{array}{l}\text { Quality of program management } \\
\text { aspect (4 items) }\end{array}$ & 5,00 & Very Good \\
\hline & Average total score & 5,00 & Very Good \\
\hline \multirow[t]{8}{*}{$\begin{array}{l}\text { Accounting } \\
\text { teachers }\end{array}$} & $\begin{array}{l}\text { Substansial and purpose aspect (13 } \\
\text { items) }\end{array}$ & 4,08 & Good \\
\hline & Instructional aspect (7 items) & 4,00 & Good \\
\hline & Readability aspect (3 items) & 4,00 & Good \\
\hline & Convenience of use aspect (1 item) & 4,00 & Good \\
\hline & Lay out quality aspect (7 items) & 3,85 & Good \\
\hline & $\begin{array}{l}\text { Program management quality aspect } \\
\text { ( } 4 \text { items) }\end{array}$ & 4,00 & Good \\
\hline & $\begin{array}{llll}\begin{array}{l}\text { Character } \\
\text { items) }\end{array} & \text { education aspect }(10 \\
\end{array}$ & 4,00 & Good \\
\hline & Average total score & 4,00 & Good \\
\hline
\end{tabular}

Product evaluation by experts shows "very good" category with average score of 4.66. product evaluation by media expert shows "very good" category due to all aspect in media evaluation got 5 as the score. Lastly, the evaluation by accounting teachers shows "good" category with average score of 4.00.

In addition to providing product assessments, experts also provide advice and suggestion to revise product. After the product was revised according to the advice and suggestion, limited try out and field try out were carried out. Total of 20 students of Tenth Accounting 1 were randomly selected for limited try out. During the trial, the researcher explained first the purpose and e-module that was developed, then the students observed and used the e-module, last the students were given a assessment questionnare of product. The questionnare contains 25 questions consisting of subject study, media, and character education aspects. The subject study aspect consists of content aspects and objectives, and instructional aspects. Media aspects consist of legibility aspects, ease to use aspects, display quality aspects, and program management aspects. Last is the aspect of character education. After a limited try out, then conducting fiels try out in $\mathrm{X}$ Accounting 3 consisting 32 students. This following are the results of a limited try out and field try out.

Table 3. Product trials result

\begin{tabular}{|c|c|c|c|}
\hline Kinds of & \multicolumn{3}{|c|}{ Evaluated Aspects and Result } \\
\cline { 2 - 4 } Trials & Evaluated Aspects & Average Score & Categories \\
\hline
\end{tabular}




\begin{tabular}{|c|c|c|c|}
\hline \multirow[t]{8}{*}{ Limited trial } & $\begin{array}{l}\text { Substantial and purpose aspect ( } 7 \\
\text { items) }\end{array}$ & 4,43 & Very Good \\
\hline & Instructional aspect ( 2 items) & 4,60 & Very Good \\
\hline & Readability aspect (3 items) & 4,42 & Very Good \\
\hline & Convenience of use aspect ( 2 item) & 4,40 & Very Good \\
\hline & Lay out quality aspect (5 items) & 4,50 & Very Good \\
\hline & $\begin{array}{ll}\text { Program management } & \text { quality } \\
\text { aspect ( } 1 \text { items) }\end{array}$ & 4,60 & Very Good \\
\hline & $\begin{array}{llll}\text { Character education aspect } & (5 \\
\text { items) }\end{array}$ & 4,49 & Very Good \\
\hline & Average total score & 4,47 & Very Good \\
\hline \multirow[t]{8}{*}{ Field trial } & $\begin{array}{l}\text { Substantial and purpose aspect (7 } \\
\text { items) }\end{array}$ & 4,33 & Very Good \\
\hline & Instructional aspect (2 items) & 4,32 & Very Good \\
\hline & Readability aspect (3 items) & 4,41 & Very Good \\
\hline & Convenience of use aspect ( 2 item) & 4,42 & Very Good \\
\hline & Lay out quality aspect (5 items) & 4,32 & Very Good \\
\hline & $\begin{array}{l}\text { Program management quality } \\
\text { aspect ( } 1 \text { items) }\end{array}$ & 4,55 & Very Good \\
\hline & $\begin{array}{llll}\begin{array}{l}\text { Character education aspect } \\
\text { items) }\end{array} & & \\
\end{array}$ & 4,27 & Very Good \\
\hline & Average total score & 4,33 & Very Good \\
\hline
\end{tabular}

Beside evaluation data of under-developed e-module product, there are a comentaries and suggestions for product upgrade. Most of the students is satisfied with the media mainly because the subject study were presented in such interestingway, it uses understandable language, animation and engaging lay out. Videos which tells student about character value motivate student to applied such value in real life. In the end, the student agreed that the accounting e-module integrated with character value make understanding accounting easier and to develop character value. It is suggested for a better product, the lay out for word and its size should be revised and some of the videos presented still in low quality.

\section{RESULT, DISCUSSION, AND SUGGESTIONS}

The product developed in this study is an accounting e-module integrated with character value for the tenth grade vocational high school students. This module contains the values of honesty and responsibility character that are in accordance with the characteristics of the accounting material. In the process of preparing an accounting e-module integrated with character value, it requires a series processes and improvements. In the line with the line with the results of the research conducted by Mumbrita \& Sukardi (2010) that suggests the process of the product improvement requires the process of the implementation periodically from the beginning up to the evaluation that conducted with experts or other experts to provide advice and suggestion that can improve appropriate product revisions for the next. Then, the next step is trial with evaluation and revision to get the final product.

Based on the experts validation, character value integrated accounting e-module is stated as valid or qualified as accounting learning media with average total score of 4.66 from subject study expert, 5.00 from media experts, and 4.00 from accounting teachers. Subject study experts agreed that basic competency and learning purpose in e-module is clearly-formulated, the subjects contained inside the e-module is precised and suitable for the aimed basic competency and learning purposes, the excersizes presented is appropriate with the subjects and can be used to calculate the indicator goals. This suits perfectly with the module compiling manual where inside of a modul there must be a basic competency, study purposes, subjects and evaluation. The subjects discussed in the modul is presented coherently, clearly and systematically, in such an interesting package that can allure readers. Instructional aspect in the module, namely example problems and illustrations marked as "very good" due to its ability to help students understand the subjects. The exercizes could motivate students to be honest and responsible which indicates the module is able to 
fasilitate the students to apply honesty and responsibility values. The average score from the subject experts is 4.66 meaning the module is categorized as "very good".

The evaluation from media experts consist of readability, convenience of use, lay out quality and program management aspects. The type of font, size and colour used in the module is appropriate which caused convenience experience among readers. Beside, the module design, background layout, text layout, animation layout and sound effect are appropriate and engaging towards the readers. Module utilization combined with technology should pay attention to program management used for module operation. The selected program should follow the development of science and technology, be easy to use, effective and efficient. The overall aspect evaluation from media experts is 5.00 which categorized as "very good".

E-module evaluation by teacher was performed because the under-developed media will be used by teachers in learning process, thus the teachers have competency in giving evaluation. The evaluated aspect from teachers consist of subjects study, media and character education aspects. Character education aspect in evaluated modul is applicable character values developed with the development of students, it also mentioned in the curriculum. The value given by the module is useful for the students and for others that the student interact with. The e-module facilitates students to practice the given value. The average score given by accounting teachers is 4.00 which categorized as "Good".

After the product is validated by the expert, the next step is to repairing the product as already suggested by the experts. The repairing itself is to product perfection before it's applied to the expert. The tryout test is applied to the students of $\mathrm{X}$ grader of Accountancy 1 Program of SMK Negeri 6 Surakarta by the tryout subject is 20 students and it was found by the score 4,47 is categorized as "Very Good." The field test also done by the X grader of Accountancy 3 program of SMK Negeri 6 Surakarta by the subject students are 32 students and it was found that the score of 4.33 is categorized as "Very Good." The overall scored aspects are study subject, media and character are categorized as "Very Good" in the second tryout test. It concludes that the udage of e-module of accountancy is integrated to the valid score or fulfilling the requirements as accountancy learning media. According to Jasson (2017), education research can produce the creation or creation of renewable products to have an impact in facilitating to convey faster information that will be received by students.

Nevertheless, the e-module has several limitations as study scope which only serves as journalizing financial report of the service company the capacity that could spend the gadget storage, however the emodule doesn't require internet connection in its operational and it can be accessed through laptop and smartphone which makes it more flexible. For the next researchers, they can develop a module with a wide range of material but do not spend a lot of storage capacity, examples of questions, exercise, and illustrations are always up to date so that they are always relevant to the current situation, and easy to use. The hope is this learning media can continue to be used, both in the class and outside the classroom.

\section{REFERENCES}

Budiyono. (2016). Statistika untuk penelitian. Surakarta: UNS Press.

Clayton T. Wukich. (2016). The formation of transnational character education in network society. Journal International Management Public, 20 (3), 381-406.

Darsono., Winarno., \& Slamet (2017). The need textbook writing of children's story based on character education. International Journal of Educational Research Review, 3 (2), 1-8.

Ismawanto (2007). Ekonomi Untuk SMA dan MA Kelas XI. Surakarta: Gema Ilmu.

Jasson, S.A. (2017). Curicula and effective learning comprehension. Journal of Education and Work, 30 (9), 700-711. 
Jeno, L.M., Grytnes, J., Vigdis., \& Vandvick. (2017). The effect of a mobile application tool on biology students' motivation and achievement in species identification: A self determination theory perspective. Computers \& Education Journal, 107, 1-12.

Kim, H.J., Pederson, S., \& Baldwin, M. (2011). Improving user satisfaction via a case-enhanced e-learning environment. Education + Training, 54 (3), 204-218.

Mumbrita \& Sukardi. (2010). Mapping potential and development humanities. Jurnal Kependidikan, 7 (2), 34-47.

Nasution, S. (2006). Berbagai pendekatan dalam proses belajar men gajar. Bumi aksara: Jakarta.

Nugraheni, B.I., \& Purwanti, R.E. (2016). Developing comic media carrying character building to teach an introduction to accounting for students of vocational high school. Advances in Economics, Business and Management Research, 4, 347-351.

Pratomo,A., Sarwanto \& Roemintoyo (2018).The development of integrative theme based instructional materials containing characteristics values of fifth grade elementary schools in Surakarta, Indonesia. International Journal of Educational Research Review,3(3),39-46.

Pummawan, A. (2007). The development of an e-learning module on the sandy shores ecosystem for grade 8 seconday student. Educational Journal of Thailand, 1 (1), 95-110.

Sengupta, D., Huang, Y., Davidson, C.I., Edgar, T.F., Eden, M., \& El-Halwagi, M. (2017). Using module based learning methods to introduce sustainable manufacturing in engineering curriculum. International Journal of Sustainability in Higher Education, 18 (3), 1-24.

Woo, T. K. (2011). Developing quality learning materials for effective teaching and learning in an ODL environment: Making the jump from print modules to online modules. Asian Association of Open Universities Journal, 6 (1), 51-58. 